LES

\title{
TRAVAUX DE DUPUY
}

SUR IE

\section{TRÉSOR DES GHARTES}

BT LES

\section{ORIGINES DU SUPPLÉMENT}

PAR

\section{H.-Francois DELABORDE}

Extrait de la Bibliothèque de l'École des chartes, Année 1897, t. LVIII.

\section{PARIS}

1897 